\title{
Obrazovanje i razvoj: kako obrazovanje razvija ljude i mijenja društvo, a kako društvo djeluje na obrazovanje
}

\author{
Institut za društvena istraživanja u Zagrebu i Učiteljski fakultet \\ Sveučilišta u Zagrebu, Zagreb, 2012., 369 str.
}

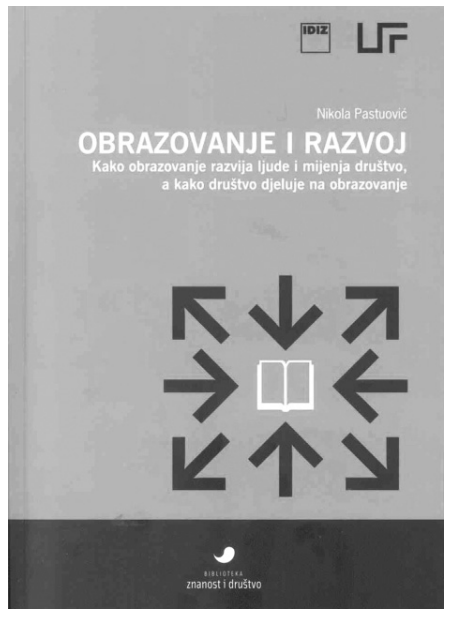

Knjiga prof. emer. dr. sc. Nikole Pastuovića Obrazovanje i razvoj: kako obrazovanje razvija ljude $i \mathrm{mi}$ jenja društvo, a kako društvo djeluje na obrazovanje novi je vrijedan znanstveni doprinos autora interdisciplinarnoj znanosti o obrazovnim sustavima te se po važnosti i sveobuhvatnosti nastavlja na autorovo ranije djelo Edukologija: integrativna znanost o sustavu cjeloživotnog obrazovanja i odgoja (1999.).

Knjiga Obrazovanje $i$ razvoj nastala je u okviru znanstvenog projekta Instituta za društvena istraživanja u Zagrebu Podizanje i ujednačavanje kvalitete obveznog obrazovanja u Republici Hrvatskoj. Knjiga sadrži predgovor, uvod, šest poglavlja (Konceptualizacija osnovnih pojmova, Obrazovanje $i$ razvoj osobe, Obrazovanje i razvoj društva, Znanost(i) o obrazovnim sustavima, Kvaliteta obrazovanja, Reforma obrazovanja), kazalo pojmova te popis priloga.

U prvim trima poglavljima autor analizira ciljeve obrazovanja, a u sljedećim poglavljima istražuje načine za njihovo ostvarenje.

U prvom poglavlju pod nazivom Konceptualizacija osnovnih pojmova autor definira pojam i vrste obrazovanja te povezane pojmove: edukacija, učenje, izobrazba, naobrazba i odgoj. Precizno se razrađuje i koncept razvoja - naglašava se kako razvoj nije jednoznačan pojam te kako postoji više područja razvoja, koja najbolje obuhvaćaju multidisciplinarna istraživanja. Autor razvoj definira kao proces promjene jednostavnije strukture u složeniju koji omogućuje djelotvornije funkcioniranje, a razvoj osobe kao „proces aktualizacije njezinih potencijala“ (str. 33). Obrazovanje može doprinijeti razvoju osobe jer je osposobljava za uspješnije zadovoljavanje potreba, te tako doprinosi samoostvarenju. Utvrđuje se i distinkcija pojmova razvoja i rasta, koji nisu u nužno pozitivnom odnosu. Autor naglašava kako je koncepcija ljudskog 
razvoja šira od teorija gospodarskog razvoja. Posebna se pažnja obraća konceptu održivog razvoja, koji doprinosi porastu kvalitete života ljudi i drugih živih bića. Naposljetku, definiraju se unutarnji i vanjski ciljevi obrazovanja te problematizira dijalektičan odnos obrazovanja i okoline, odnosno različitih društvenih podsustava.

U drugom poglavlju, Obrazovanje i razvoj osobe, objašnjava se što je ličnost, kako se razvija te koliki utjecaj na razvoj ličnosti imaju nasljeđe i okolina. Posebno je važno što autor drži naobrazbu osobinom ličnosti jer je relativno trajna i univerzalna osobina koja utječe na ponašanje pojedinca u raznim situacijama. Štoviše, navodi se kako je naobrazba, uz opću inteligenciju, najvažnija kognitivna osobina ličnosti. Osobito je važna činjenica da različite osobe u istoj okolini imaju različitu mogućnost za iskorištavanje te okoline. Zbog toga bi nastava trebala biti prilagođena učeniku kako bi se obrazovni i odgojni proces najučinkovitije odvio. Također, autor ističe značaj predškolskog doba u kojem je mozak izrazito prijemčiv za učenje i u kojem se polažu temelji za buduće obrazovanje. Stoga autor ističe važnost obuhvata i dostupnosti predškolskog odgoja i obrazovanja za svu djecu, neovisno o njihovom socijalnom porijeklu, te se navodi kako bi prosvjetna politika trebala osigurati kvalitetne i besplatne programe za svu djecu. Raspravlja se i o vezi odgoja i moralnog razvoja osobe, o temperamentu i odgojivosti te motivima za ponašanje. Razmatra se ograničena moć obrazovanja, pro i antisocijalno ponašanje te veza s odgojivošću. Opisuje se i kontroverzan odnos obrazovanja i moralnosti, te se napominje kako „na moralnost i moralno ponašanje više djeluje iskustveno učenje nego školovanje“ (str. 158).

Treće poglavlje, Obrazovanje i razvoj društva, prikazuje odnos obrazovanja i gospodarskog, političkog, kulturnog i ekološkog razvoja. Autor navodi kako se ulaganje u obrazovanje isplati na individualnoj i društvenoj razini, ali ekonomska isplativost obrazovanja ovisi o drugim društvenim pojavama: usklađenosti obrazovne produkcije i tržišta rada, kvaliteti znanja koje se stječe i mogućnosti da se znanja i vještine upotrijebe. Stoga autor navodi kako obrazovna ekspanzija ne vodi automatski gospodarskom rastu i razvoju. Također, obrazovanje doprinosi političkom razvoju stvaranjem nacionalnog identiteta i integracije, ali s većim stupnjem obrazovanja pojedinaca dolazi i do veće kritičnosti prema politici i postojećem poretku. Autor razmatra i utjecaje obrazovanja i odgoja na kulturu nekog društva. Navodi se kako „edukacija na kulturu više djeluje odgojem nego obrazovanjem“ (str. 173), pa je moguće biti obrazovan, ali ne biti odgojen. Ljudska prava, kao vrijednosti koje se prenose odgojem, mogu poboljšati kvalitetu života i utjecati na gospodarski ili politički razvoj. Ističe se i kako obrazovanje ima ulogu u razvoju ekološke svijesti i ponašanja, no samo ekološko obrazovanje nije garancija ekološkog ponašanja, već je potrebno odgojem razvijati vrijednosti i stavove koji motiviraju za takvo ponašanje. Obrađuju se i pojmovi ljudskog i socijalnog kapitala. Visoka razina socijalnog kapitala obitelji i škole pozitivno je povezana sa školskim uspjehom djece, ali i s gospodarskom i demokratskom razvijenosti, te je pretpostavka za razvoj društva znanja.

U četvrtom poglavlju, Znanost (i) o obrazovnim sustavima, autor određuje predmet i metodologiju navedene znanosti te kriterije za utvrđivanje znanstvenosti neke teorije. Poziva se na Brezinku u određenju predmeta odgojnih znanosti: to je istraživanje „odnosa cilj-sredstvo“ u području edukacije. Autor smatra kako treba istraživati rea- 
litet, stvarne ciljeve obrazovne djelatnosti, a ne željene ciljeve. Izlaže se model obrazovanja kao sustava s karakteristikama organizacije koja ima svoje ulaze u obrazovni sustav, resurse, transformacijske procese, izlaze i ishode. Kako bi se u potpunosti razumjelo složen sustav poput obrazovnog, autor se zalaže za primjenu otvorenog sustavskog pristupa koji raščlanjuje međuodnose dijelova sustava. Takav se pristup može koristiti na svim razinama obrazovanja te "predstavlja metodologiju znanosti o obrazovnim sustavima koja je za nju specifična" (str. 240). Posebno je važan pojam edukologije, znanosti o obrazovnim sustavima, koja sabire i suočava sve vrste znanja o obrazovanju. Razlika od pojedinih obrazovnih znanosti je u činjenici da se ne fokusira na jedan cilj edukacije, već „istražuje sredstva za optimalno ostvarivanje svih edukacijskih ciljeva“ (str. 250). Autor razmatra i pedagogiju kao znanost, te je smatra normativnom i deskriptivnom disciplinom koja znanstvenim dosezima ne može parirati razvijenijim obrazovnim znanostima.

U petom poglavlju pod nazivom Kvaliteta obrazovanja autor definira kvalitetu obrazovanja kao kvalitetu ishoda - kognitivnih i afektivnih postignuća učenika. Definiranje i unapređivanje kvalitete obrazovanja važno je jer se smatra presudnim za međunarodnu kompetitivnost i gospodarski razvoj. U društvu znanja važno je ostvariti ne samo visoku razinu obrazovnih postignuća nego i što manje razlike među školama i regijama, uz što niži utjecaj socioekonomskog statusa obitelji na obrazovna postignuća djece. Dva su značajna pokazatelja kvalitete obrazovanja: vanjsko vrednovanje ishoda na kraju osnovnog i srednjeg obrazovanja te podaci međunarodnih komparativnih istraživanja izlaza i kvalitete obrazovnih ishoda. Potonji podaci pokazuju kako djeca iz obrazovnih sustava s najnižim stupnjem diferencijacije postižu najviše prosječne rezultate u čitalačkoj pismenosti jer rana horizontalna diferencijacija pojačava djelovanje obiteljskog ekonomskog, kulturnog i socijalnog statusa, što dovodi u nepovoljan položaj djecu iz neprivilegiranih obitelji. Na testiranju PISA hrvatski učenici postižu rezultate koji su ispod prosjeka OECD-a u svim područjima procjene. Autor stoga preporučuje odgađanje horizontalne diferencijacije do učenikove šesnaeste godine, što znači da je optimalno trajanje osnovne škole devet godina. Od posebne je važnosti autorov zaključak kako je potrebno i srednju školu proglasiti obaveznom kako bi se omogućilo stjecanje barem prve kvalifikacije. Autor analizira i pojmove kurikulumskog sustava i kurikulumskih procesa, pri čemu se napominje kako je posebno značajan kurikulum osnovnog obrazovanja, te ga treba saturirati znanjima najveće transferne vrijednosti.

U zadnjem poglavlju pod nazivom Reforma obrazovanja autor razmatra različite moguće modifikacije u obrazovanju, kao i vezu s društveno-ekonomskim promjenama. Autor se posebno referira na zemlje Središnje i Istočne Europe, u kojima su moguća četiri tipa reformi: korektivne, modernizirajuće, strukturne i sistemske (prema Birzea, 1996.). Napominje se kako u postkomunističkim zemljama, zbog zakašnjelog društvenog razvoja, treba provesti modernizirajuću, ali i strukturnu i sustavsku obrazovnu tranziciju. Autor navodi kako je važan cilj obrazovne politike povećanje jednakosti obrazovnih prilika kroz dodatnu potporu rizičnim skupinama - važno je da međuškolske razlike ne budu veće od unutarškolskih, stoga država treba osigurati podjednake uvjete učenja diljem zemlje, što zahtijeva ulaganja u optimizaciju školske mreže. Uspoređujući hrvatski obrazovni sustav s onima drugih država, autor 
zaključuje da je po strukturnim značajkama bolji od srednjoeuropskog, ali lošiji od skandinavskog. Autor objašnjava zašto je optimalno trajanje primarnog obrazovanja šest, a ne četiri godine i zašto je optimalno trajanje osnovnog obrazovanja devet, a ne osam godina, a predstavljene su i prednosti i nedostaci dvaju mogućih modela produljenja obveznog obrazovanja u Hrvatskoj.

Bogata znanstvena karijera, ali i višekratna uključenost u procese kreiranja ključnih dokumenata iz područja strateškog planiranja obrazovanja za Vladu Republike Hrvatske omogućili su autoru jedinstven i cjelovit uvid u područje odgoja i obrazovanja, upravo onakav kakav u Hrvatskoj nedostaje zbog još uvijek malog broja interdisciplinarnih istraživanja obrazovanja. Knjiga Obrazovanje i razvoj neizostavna je za sve koji se na bilo koji način bave odgojnim i obrazovnim sustavom ili se za njega zanimaju, za sve koji žele razumjeti kompleksnost obrazovnog sustava i njegovu međuovisnost o drugim dijelovima društva. Knjiga bi trebala postati temeljna literatura ne samo za studente pedagoških smjerova nego i za druge sudionike odgojno-obrazovnih procesa, kreatore obrazovne politike, istraživače i može se preporučiti svima kojima je stalo do napretka i razvoja društva temeljenog na znanju, ali i socijalnoj pravdi.

Iva Košutić

Institut za društvena istraživanja u Zagrebu 